\title{
The Effects of Quality Books for Children and the Metacognitive Strategy on Students' Self-Esteem Levels
}

\author{
Erkan $\mathrm{Cer}^{1} \&$ Ertugrul Sahin ${ }^{2}$ \\ ${ }^{1}$ Department of Turkish Education, Amasya University, Amasya, Turkey \\ ${ }^{2}$ Department of Guidance and Psychological Counseling, Amasya University, Amasya, Turkey \\ Correspondence: Ertuğrul Şahin, Department of Guidance and Psychological Counseling, Faculty of Education, \\ Amasya University, Turkey. Tel: 90-358-252-6230. E-mail: ertugrulsahn@gmail.com
}

Received: September 12, 2016

doi:10.5539/jel.v6n1p72

\author{
Accepted: October 20, 2016 Online Published: November 8, 2016 \\ URL: http://dx.doi.org/10.5539/jel.v6n1p72
}

\begin{abstract}
Using a quasi-experimental design with pre-test and post-test control groups, 93 eighth grade students were randomly assigned either to the experimental or to the control group and responded to the Rosenberg Self-Esteem Scale two weeks before and after the intervention. While the students in the experimental group were instructed in quality books for children and reading comprehension skills based on metacognitive strategy for 10 weeks, the control group only received typical non-quality books. Study results showed that while the pre-test self-esteem scores of the students in both groups were similar before the intervention, the post-test self-esteem scores of the students in the experimental group were significantly higher than of those in the control group. Quality books and metacognitive strategy for students may not only help improve reading comprehension but also may increase self-esteem level.
\end{abstract}

Keywords: the metacognitive strategy, reading comprehension instruction, self-esteem, secondary school students, Turkey

\section{Introduction}

Metacognitive strategy is defined as controlling, monitoring, evaluating, and self-regulating in order to reach the subtext during the reading process (Roeschl-Heils, Schneider, \& van Kraayenoord, 2003). This strategy is based on cognitive skills including perception, grasping, synthesizing, analyzing, and evaluating about what will be read, as well as why and how it will be read in pre-reading, during-reading, and post-reading processes, and purposefully restructures several relationships between the reader and the book (Pressley, 2002). It is a well-known fact that using the metacognitive strategy during reading process is helpful to students. Researches have shown that enhancing reading comprehension through the metacognitive strategy has a positive effect on the individual's self-concept, self-efficacy, motivation, and academic achievement (Li \& Wang, 2010; Piran, 2014; Shang, 2011; Zarei, Shokrpour, Nasiri, \& Kafipour, 2012). Therefore, improving reading comprehension through the metacognitive strategy also improves the quality of reading comprehension, and controlling, evaluating and self-regulating processes (Greenberg, 2008; Guindon, 2010). This strategy also enhances self-motivation (Efklides, 2011), as it can regulate pre-reading, during-reading, and post-reading processes (Schraw, 1998). Furthermore, the individual develops self-awareness for his cognition as he has the chance to engage in self-monitoring throughout the reading comprehension process (Flavell, Miller, \& Miller, 2002). Within all these aspects of the reading comprehension process, the individual's displaying emotions, ideas, and attitudes by becoming aware of his realistic perception, engaging in self-regulation, and realizing his skills and abilities may help enhance self-worth because the individual manifests judgments concerning himself and several situations within the reading comprehension process.

Self-esteem is defined as positive and negative attitudes towards the self (Rosenberg, 1965). It is one of the foundation elements for shaping self-image (Branden, 1994), in increasing motivation (Kernis, 2003), and in retaining success. Researches have shown that self-esteem is an indispensable variable for a happy and healthy life not only in western cultures (Heine, Lehman, Markus, \& Kitayama, 1999) but also in Asian (Zhang, 2005) and Middle Eastern societies (Hobfoll \& Leiberman, 1987). The fact that positive self-esteem in particular plays a crucial role in children's character development is well-known by many societies and helps them pay particular attention to building self-esteem in the early years of childhood (Shaw, Liang, \& Krause, 2010). Regarding the 
sociocultural perspective, the reason for enhancing people's self-esteem is to facilitate the transfer of information between the individual and the social environment that will protect him from negative experiences (Zeigler-Hill, 2013). Achievement, self-confidence, and self-efficacy are important variables for this inclination (Guindon, 2010). Restructuring these variables in a healthy way in the individual's life may help him affirm his self-worth. There is a bidirectional link in particular between achievement and self-esteem, because one of the hindrances to achievement is not related to ability and skills but to the lack of self-esteem. Moreover, success may not be achievable without self-esteem. In this respect, self-esteem may result in important affective factors for achievement and reduce failure (Zeigler-Hill, 2013).

Although there have been several studies on the relationship between reading comprehension and self-esteem (Bagheri \& Faghih, 2012; Guindon, 2010; Juyandegan, 2016; Koosha, Abdollahi, \& Karimi, 2016), the most basic limitation of these studies is either their lack of strategy or the exclusion of books of literary quality, which are supposed to develop these variables, from the research process. Therefore, by emphasizing that self-esteem is enhanced only through reading comprehension, the importance of variables that assists the comprehension process cannot be accentuated. Secondly, there has been no research in which the effect of reading comprehension on self-esteem is analyzed through both the metacognitive strategy and children's books of literary quality in the Turkish culture. Thirdly, the program, of which aim was to improve reading and reading comprehension, has been performed on lists of the 100 Classical Works prepared by the Ministry of Education in Turkey in 2005 (Ministry of Education, 2005). Whether reading comprehension using the metacognitive strategy to read books from the Turkish and world classics on this list enhances self-esteem or not has also not been researched. All the mentioned reasons reveal the necessity for this study.

\subsection{Reading Comprehension and Self-Esteem through the Metacognitive Strategy}

Self-esteem mainly exposes motivation, achievement, ability, and self-confidence during the reading process (Guindon, 2010). Thus, the individual's judgments about his reading skills may influence self-worth. Furthermore, the individual's reading and reading comprehension skills may be a direct indicator of the level of his self-esteem because, people with low self-esteem are not able to express their feelings and ideas efficiently (Timothy, Sheldon, \& Norman, 2001).

An individual uses a series of strategies to enhance and maintain his feelings and ideas about his self-worth. In other words, people with different levels of self-esteem tend to adapt to various strategies in order to regulate what they feel about self-worth (Zeigler-Hill, 2013). In this respect, the individual's perceptions and experiences which emerge with the help of the metacognitive strategy during the reading comprehension process may alter what he feels about himself (Schiraldi, 2007), because the individual will try to adapt to the processes of planning, self-control, self-assessment, and self-regulation while improving reading comprehension skills through the metacognitive strategy. Thus, the individual may engage in self-regulation only after he accepts and evaluates his self-image, which he restructures via his own thoughts and feelings. In this regard, self-esteem is associated with the individual's perception rather than reality (Zeigler-Hill, 2013).

\subsection{Self-Esteem and Quality Works of Children's Literature}

The child may identify with the character's emotions and thoughts, and he may share the character's excitement or internalize attitudes and behaviors that he reflects in while solving a problem. This situation may affect the child's self-image both negatively and positively and, naturally, his self-esteem. Thus, the child may have the opportunity to engage in affective and cognitive self-assessment, self-control, and self-monitoring because his use of self-regulation means that he notices the differences among his emotions, thoughts, attitudes, and behaviors, which reflect his self-image (Zeigler-Hill \& Showers, 2007).

Experiences and perceptions may alter what we feel about ourselves. In this regard, efficient stimuli that portray behaviors, emotions, images, thoughts, and attitudes may be useful in structuring self-esteem (Schiraldi, 2007). The child's interaction with quality works of children's literature, which he admires and which are appropriate for his age and developmental level, may enhance his self-esteem, which is accepted as one of the variables that emerge when the individual encounters desired activities (Sheldon, Elliot, Kim, \& Kasser, 2001). The child's interaction with the books he likes and embarking on an adventure not only enhances his self-esteem but also has positive effects on his learning and academic achievement (Schunk, 1999).

Improving the child's reading comprehension skills may also ensure affective development because it is a known fact that children identify with the characters in books, and adopt their values more easily. Children who identify with heroes in these kinds of books make a habit of analyzing, evaluating, interpreting, and inferring from 
situations/actions, and, most importantly, examining themselves and engaging in self-regulation (Çer, 2016a; Aslan, 2011).

\subsection{The Current Study}

Despite previous studies found evidence for effectiveness of interventions for self-esteem and the metacognitive strategy in students, researchers rarely used these interventions simultaneously as well as used quality books in interventions. Thus, the purpose of this study was to examine the effect of the reading comprehension instruction program, which is based on the metacognitive strategy and quality books for children on self-esteem. It was hypothesized that students in the experimental group would have higher self-esteem than the students in the control group because they were given an instruction based on the metacognitive strategy, and quality books.

\section{Method}

\subsection{Participants and Procedure}

Ethical approval about study protocol was obtained from Amasya University Ethic Committee before the intervention as well as necessary permission from local education authorities. Students were informed about the purpose of the study, voluntary participation as well as about withdrawal right before the study. All students gave written consent to participate in the study. No students in the experimental and control group refused to participate. A quasi-experimental design with pre-test and post-test control group was used in this study. There were 45 ( 23 males, 22 females) students in the control group and 48 ( 21 males, 27 females) in the experimental group. The age range of the students was 13 to 15 and the mean age of participants was 14.43 (S.D: .50). No further information about the demographic characteristics of the students in the control and experimental groups was collected. The students in the eighth grade from two different classes who volunteered to participate in the study were randomly assigned to either the control or the experimental groups. The eighth grade students were especially selected for this study because they take the Examination for the Transition to Basic Secondary Education (TEOG) in Turkey, which over 1.8 million students take, with the aim of admission to selective high schools, such as Anatolian Teacher Training High School and Medical Vocational High School. These high schools provide students with high prospective education, career, and job opportunities, such as a good job and a quality university education. However, only $15 \%$ of these students have the opportunity to enroll in these schools. For this reason, to be able to be successful in this exam, having a good level of reading comprehension is an important asset for many eighth grade students.

\subsection{Measures}

Rosenberg Self-Esteem Scale (RSES): The RSES (Rosenberg, 1965) was used to measure students' self-esteem levels. Çuhadaroğlu (1986) implemented the reliability and validity study of this scale in Turkish adolescents. The validity of the RSES was examined via psychiatric interviews and reported as .71. The one-month test-retest reliability reported was .75. In a Turkish early adolescent sample, the internal consistency estimates of the RSES scores reported to be .77 (Şahin, Barut, \& Ersanl1, 2013). The RSES consists of 10 items whose responses are made on a four-point Likert type scale consisting of Strongly Disagree (1), Disagree (2), Agree (3), or Strongly Agree (4). Scores may range from 10 to 40 . Higher scores indicate higher levels of self-esteem. An example item from the RSES is: "On the whole, I am satisfied with myself".

\subsection{Structured Instruction}

The control and the experimental groups were given two different instructions. Firstly, the students in the experimental group were taught how they would use the metacognitive strategy with books of literary quality to enhance reading comprehension for the first week. This instruction was composed of three parts, including the procedures to be followed in pre-, during-, and post-reading processes and questions used in these process validated in previous studies (Anderson, 2002; Andrade, 1999; Ekbatani, 2000; Manzo \& Manzo, 1995; Schraw, 1998; Statman, 1993; Zimmerman, 1995). Through this instruction provided for the experimental group, the students were tested to discern whether reading through the metacognitive strategy was different from other strategies throughout the first week of the reading comprehension process. Accordingly, items in this strategy were explained one by one in pre-, during-, and post-reading processes, and they were taught how to affectively, cognitively, and behaviorally read. Since it was difficult to implement this process on a class level, the students were divided into five groups. Thus, the researchers were able to explain each one of the items to students individually. During one week, each different group was simply tested daily in order to determine whether they understood the items in the metacognitive strategy. As a result of this simple procedure, all students knew what they should do in pre-, during-, and post-reading processes. The students in the control group were instructed in reading and reading comprehension through the texts of the 100 Classic Works, which are used in traditional 
education within the Turkish teaching program. During this instruction, no strategies were used to help students' reading comprehension. They were only asked questions such as "What did you find out?"; "What might be the main theme of the book?" and "What is the character in the book doing?".

Table 1. Using metacognitive strategy in pre-, during-, and post-reading processes

Pre-Reading Strategy:

Planning

1. Setting a reading goal

2. Determining what kind of strategy is required

3. Revising the text to activate foreknowledge or creating the initial theory about the text

4. Utilizing the title of the text, paragraphs, and visuals to obtain preliminary meaning from the text

5. Specifying how much time and how many sources are required

6. Forming the microstructure of the text, depending on foreknowledge

7. Anticipating the content of the text

8. Creating questions about what the gist of the text might be and trying to produce responses

9. Arranging the generated gist and using it to grasp the structure of the text

10. Comparing the gist with various main themes

11. Creating a visual image for the depiction of the text

12. Making estimates for the content of the text

13. Inferring from the text to grasp the theme thoroughly

14. Evaluating the main theme

15. Generating emotional reactions to the text

During-Reading Strategy:

Self-Monitoring

16. Comprehending the text completely

17. Determining whether any changes in the reading goal are required

18. Becoming aware of the problems within the text

19. Becoming aware of the individual difficulties in comprehending the text

20. Realizing the errors while replying to the questions and revising those errors

21. Rereading the complicated parts to overcome the difficulty in comprehending

22. Determining whether there is information that could help overcome the difficulty of comprehending by scanning and skimming

23. Using the clues in the text to interpret a difficult phrase or clause

24. Making educated guesses about the meaning of a difficult phrase or clause depending on the structural quality of the text

Post-Reading Strategy:

Self-Assessment

25. Creating a cohesive summary of the text

26. Restructuring and evaluating the hypothesized microstructure of the text

27. Rereading certain parts of the text to render the difficult parts understandable

28. Evaluating the quality or the content of the text 


\subsection{Works of Children Literature}

The experimental group was also instructed in quality books for children and in reading comprehension skills based on the metacognitive strategy for 10 weeks. Quality books for children indicate to books taking into account the attention, needs, and language universe of children as well as their developmental and cognitive levels in terms of design, contents, and educational qualities (Çer \& Şahin, 2016). We evaluated quality and non-quality books based on criteria developed by Çer and Şahin (2016-Appendix A) and offered students these quality books (Çer \& Şahin, 2016, Appendix B). In this study, the students in the experimental and the control groups were given various books for 10 weeks. Interventions lasted one lesson hour or about 45 minutes per week. They were told that they were supposed to read one book per week and they were going to be tested in reading comprehension at the end of 10 weeks. Hence, the students in the experimental group were given quality works of children's literature appropriate for their developmental level. Example books given the students were "The Cucumber King" (Christine Nöstlinger), "Paul Street Boys" (Ferenc Molnar), "The Boy in the Striped Pyjamas" (John Boyne), "The Little Prince" (Antoine de Saint-Exupery), "My Name is Nobody" (Frank Cottrell Boyce), "A Necklace of Raindrops" (Joan Aiken and Jan Pienkowski). These books were appropriate for the students' linguistic and cognitive levels in terms of design, content, and educational attributes (Çer \& Şahin, 2016).

The students in the control group were asked to read 10 books from the 100 Classic Works approved by the Ministry of Education. Example books given the students were "VatanYahut Silistre" (Namık Kemal), "Ömer'in Çocukluğu" (Muallim Naci), "The Wild White Stallion" (Rene Guillot), and "The Old Man and Sea" (Ernest Hemingway). Just like the program practiced on the experimental group, they were told that one book was supposed to be read per week and they were going to be tested in reading comprehension.

\subsection{Data Analysis}

All statistical analyses were performed with SPSS 23. The independent samples t-test was used to compare pre-test scores of participants in the control and the experimental groups. One-Way Analysis of Covariance (ANCOVA) was used to examine the difference in the groups' post-intervention scores controlling for pre-test scores. The statistical significance level was set at .05 in all the statistical analyses.

\section{Results}

Table 2 shows the means and standard deviations in the experimental and the control groups before and after intervention. The independent samples t-test result showed that there was no significant difference $(t$ $(86.05)=1.86, p>.05, d=.38)$ in pre-test scores between the students in the control $(M=19.50, S D=2.60)$ and the experimental $(M=18.62, S D=1.91)$ groups. However, there was a medium (.38 standard deviation) effect size in favor of the experimental group. Thus, we conducted a One-Way ANCOVA to test post-intervention self-esteem score differences between groups controlling for pre-test scores. One way ANCOVA result showed in Table 3. As seen in Table 3, The one-way ANCOVA results were significant $(F(1,90)=2130.86, p<.001, d=9.67)$ indicating that self-esteem scores $(M=35.19, S D=1.63)$ of the students in the experimental group were significantly higher than those of the students in the control group $(M=18.42, S D=1.89)$ controlling for their pre-test scores. The intervention has a large effect size $(d=9.67)$.

Table 2. Descriptive statistics

\begin{tabular}{lcccc}
\hline & \multicolumn{2}{c}{ Pre-Test } & \multicolumn{2}{c}{ Post-Test } \\
\cline { 2 - 5 } & $M$ & $S D$ & $S D$ & 1.84 \\
\hline Control & 18.62 & 1.91 & $18.42_{\mathrm{b}}$ & 1.63 \\
\hline
\end{tabular}

Note. Each number with a subscript in the means indicates a group difference: $\mathrm{a}>\mathrm{b}$. 
Table 3. One way ANCOVA results

\begin{tabular}{llllll}
\hline Source & Type III Sum of Squares & $d f$ & Mean Square & $F$ & $p$ \\
\hline Corrected Model & $6533.664^{*}$ & 2 & 3266.832 & 1093.767 & $.001^{*}$ \\
Intercept & 1084.755 & 1 & 1084.755 & 363.186 & $.001^{*}$ \\
Pre-test & 5.481 & 1 & 5.481 & 1.835 & .179 \\
Experimental Group & 6364.398 & 1 & 6364.398 & 2130.862 & $.001^{*}$ \\
Error & 268.809 & 90 & 2.987 & & \\
\hline
\end{tabular}

Note. $p<.001^{*}$.

\section{Discussion}

This study examined the effectiveness an intervention aiming to improve self-esteem based on the metacognitive strategy and quality books. Consistent with our hypothesis as well as previous studies only using neither self-esteem intervention (Bagheri \& Faghih, 2012; Juyandegan, 2016; Koosha, Abdollahi, \& Karimi, 2016) nor the metacognitive strategy (Li \& Wang, 2010; Piran, 2014), it was found that the metacognitive strategy based on reading comprehension also enhances self-esteem together with students' reading comprehension skills. However, unlike the previous studies, both the metacognitive strategy and quality books to improve self-esteem and intervention were very efficient. One possible reason for this effectiveness may be that the students were not instructed on any metacognitive strategy in the control group. For this reason, students were not able to totally understand the themes in the texts or restructure and express their emotions and thoughts. Another reason may be that books used in the control group from the 100 Classic Works were not appropriate for their developmental and age levels (Children's and Youth Literature Practice and Research Center, 2016) because these books prioritized Turkish customs, traditions, and Islamic values (Çer, 2015; Kansu-Yetkiner, 2014). Since students' understanding of books requires that they be appropriate for their developmental levels (Çer, 2016a, 2016b, 2016c), these books hindered them from thinking critically, creatively, and analytically, may cause them to be passive participants.

On the other hand, in the experimental group, the students' inclusion in planning, monitoring, and self-assessment processes with metacognitive strategy led them to positive judgments about their self-worth. In other words, the students who used metacognitive strategy in the experimental group tried regulating their feelings about self-esteem with the processes of criticizing, evaluating, inferring, estimating, cause and effect relationships, and generating genuine opinions from what they read because students' experiences and perceptions emerged in the reading comprehension process through the metacognitive alteration of the way they felt about themselves (Schiraldi, 2007). Furthermore, giving students appropriate books for their developmental and age levels helped them become aware of their own feelings, ideas, behaviors, and attitudes. This fact contributed to the development of accepting and caring about other people, and self-confidence processes were improved by regarding the actions and facts in the books.

This study proposed that children's books of literary quality might be read through the metacognitive strategy to enhance students' self-esteem levels. Using the metacognitive strategy with quality books helped students better understand what they read, and restructure the process of their self-worth because the metacognitive strategy can help turn a child into a self-confident, successful, and a responsible participant with its planning, monitoring, evaluating, self-regulating, and self-correcting processes (Anderson, 2002). Thus, the child can efficiently express his feelings and thoughts by enhancing his comprehension level. This also contributes to the child's social and personal development (Efklides, 2011) because children who efficiently express what they understand become more sociable, more self-confident, and more successful (Lau \& Chan, 2003).

The first limitation of this study is the uncertainty about how long the students' self-esteem development along with their metacognitive skills might continue. Further experimental research with follow-up studies should be performed. Secondly, this study was performed only on eighth grade students. For this reason, different educational levels should be studied to determine the effectiveness of the strategy on self-esteem. Lastly, only 10 books from the 100 Classic Works for the control group and only 10 quality books for children for the experimental group were utilized for the reading process. Further studies that employ other books from the 100 Classic Works and various quality books for children should be carried out. Studies have consistently shown that students experience a number of academic and emotional problems (Topkaya, 2014a, 2014b; Topkaya \& Meydan, 2013) and improving mental health of these students is a key concern for most school counselors. One 
possible way to improve mental health for students may be recommend students to read quality books. Future studies may also investigate the effectiveness of reading quality books on students' other psychological characteristics.

In summary, it was found that the self-esteem levels of the students were enhanced by reading quality books for children using metacognitive strategy. Instead of giving short answers to the questions about books of literary quality given in the control group, the students in the experimental group operated some higher order processes, such as setting cause and effect relations, contrasting, associating, estimating, evaluating, as well as engaging in self-regulation, and this made a positive contribution to their perceptions about their self-worth. All these situational processes helped them pass from passive recipient to the meaning-generating position. Thus, the students became efficient participants restructuring their memories using metacognitive strategy and quality books for children.

\section{Acknowledgments}

E.Ş participated in designing the data collection instruments, performed data collection and analyses, drafted the manuscript. E.Ç and E.Ş performed data collection, participated in designing the instruments, reviewed and revised the manuscript. E.Ç conceptualized and designed the study, designed the data collection instruments, coordinated and supervised data collection, implemented to intervention, and critically reviewed the manuscript. All authors approved the final manuscript as submitted.

\section{References}

Anderson, N. J. (2002). The role of metacognition in second/foreign language teaching and learning. ERIC Digest, Washington: ERIC Clearinghouse on Languages and Linguistics.

Andrade, H. (1999). Student self-assessment: At the intersection of metacognition and authentic assessment. ERIC Document No. ED 431030.

Aslan, C. (2011). Soru sorma becerilerini geliştirmeye dönük öğretim uygulamalarının öğretmen adaylarının soru oluşturma becerilerine etkisi [Effects of teaching applications for developing question asking skills on question forming skills of prospective teachers]. Ĕgitim ve Bilim Dergisi, 36(160), 238-249.

Bagheri, M. S., \& Faghih, M. (2012). The relationship between self-esteem, personality type and reading comprehension of Iranian EFL students. Theory and Practice Language Studies, 2(8), 1641-1650. http://dx.doi.org/10.4304/tpls.2.8.1641-1650

Branden, N. (1994). The six pillars of self-esteem. New York: Bantam.

Çer, E. (2015). One step forward and two steps back: A study of the image of woman in the 100 basic works of literature in Turkey. Universal Journal of Educational Research, 3(12), 1008-1014. http://dx.doi.org/10.13189/ujer.2015.031209

Çer, E. (2016a). Çocuk edebiyatı: 0-6 yaş çocuk kitaplarında çocuk gerçekliği ve çocuğa görelik. Ankara: Eğiten Kitap.

Çer, E. (2016b). Preparing for books children from birth to six: The approach of appropriateness for the child. Journal of Education and Practice, 7(6), 78-99.

Çer, E. (2016c). Preparing for books children from birth through six: A new children's reality approach. Universal Journal of Educational Research, 4(5), 1024-1036. http://dx.doi.org/10.13189/ujer.2016.040512

Çer, E., \& Şahin, E. (2016). The acquaintance level of Turkish prospective teachers with qualified works of children's literature. Journal of Education and Learning, 5(3), 205-219. http://dx.doi.org/10.5539/jel.v5n3p205

Children's and Youth Literature Practice and Research Center. (2016). Illköğretim döneminde çocuklara seslenen yapitlar [Appropriate children's books for primary schools]. Retrieved April 4, 2016, from http://cogem.ankara.edu.tr/

Çuhadaroğlu, F. (1986). Adolesanlarda benlik saygısı [Self-esteem in adolescents] (Yayımlanmamış Uzmanlık Tezi). Hacettepe Üniversitesi, Ankara.

Efklides, A. (2011). Interactions of metacognition with motivation and affect in self-regulated learning: The MASRL model. Educational Psychologist, 46, 6-25. http://dx.doi.org/10.1080/00461520.2011.538645

Ekbatani, G. (2000). Moving toward learner-directed assessment. In G. Ekbatani, \& H. Pierson (Eds.), Learner-Directed Assessment in ESL (pp. 1-11). New Jersey: Mahwah. 
Flavell, J. H., Miller, P. H., \& Miller, S. A. (2002). Cognitive development (4th ed.). Englewood Cliffs, NJ: Prentice-Hall Publishing.

Greenberg, J. (2008). Understanding the vital human quest for self-esteem. Perspectives on Psychological Science, 3, 48-55. http://dx.doi.org/10.1111/j.1745-6916.2008.00061.x

Guindon, M. H. (2010). What do we know about self-esteem interventions? In M. H. Guindon (Ed.), Self-esteem across the lifespan: Issues and interventions (pp. 3-25). New York: Routledge.

Heine, S. J., Lehman, D. R., Markus, H. R., \& Kitayama, S. (1999). Is there a universal need for positive self-regard? Psychological Review, 106, 766-794. http://dx.doi.org/10.1037/0033-295X.106.4.766

Hobfoll, S. E., \& Leiberman, J. R. (1987). Personality and social resources in immediate and continued stress resistance among women. Journal of personality and social psychology, 52(1), 18-26. http://dx.doi.org/10.1037/0022-3514.52.1.18

Juyandegan, M. (2016). The relationship between self-esteem and reading comprehension of efl ranian pre-university learners. International Journal of Asian Social Science, 6(5), 303-313. http://dx.doi.org/10.18488/journal.1/2016.6.5/1.5.303.313

Kansu-Yetkiner, N. (2014). Words apart, worlds apart: Peritexts from islamized translations of world classics in children's literature. Children's Literature in Education, 45(4), 340-353. http://dx.doi.org/10.1007/s10583-014-9218-y

Kernis, M. H. (2003). Toward a conceptualization of optimal self-esteem. Psychological Inquiry, 14, 1-26. http://dx.doi.org/10.1207/S15327965PLI1401_01

Koosha, M., Abdollahi, A., \& Karimi, F. (2016). The relationship among efl learners' self-esteem, autonomy, and reading comprehension. Theory and Practice in Language Studies, 6(1), 68-78. http://dx.doi.org/10.17507/tpls.0601.09

Lau, K. L., \& Chan, D. W. (2003). Reading strategy use and motivation among Chinese good and poor readers in Hong Kong. Journal of Research in Reading, 26(2), 177-190. http://dx.doi.org/10.1111/1467-9817.00195

Li, Y., \& Wang, C. (2010). An empirical study of reading self-efficacy and the use of reading strategies in the Chinese EFL context. Asian EFL Journal, 12(2), 144-162.

Manzo, A., \& Manzo, U. (1995). Teaching children to be literate: A reflective approach. USA: Holt Rinehart and Winston.

Ministry of Education. (2005). 100 Temel Eser'in Tam Listesi [The Complete List of 100 Basis Works]. Ankara: Ministy of Education Republic of Turkey. Retrieved May 25, 2015, from http://www.meb.gov.tr/duyurular/duyurular/100TemelEser/100TemelEser Genelge.htm

Piran, N. A. (2014). The relationship between self-concept, self-efficacy, self-esteem and reading comprehension achievement: Evidence from Iranian EFL learners. International J. Soc. Sci. \& Education, 5(1), 58-66.

Pressley, M. (2002). Metacognition and self regulated comprehension. In A. E. Farstrup, \& S. J. Samuels (Eds.), What research has to say about reading instruction (pp. 291-309). Newark: International Reading Association. http://dx.doi.org/10.1598/0872071774.13

Roeschl-Heils, A., Schneider, W., \& van Kraayenoord, C. (2003). Reading, metacognition, and motivation: A follow-up study of German students in grades 7 and 8. European Journal of Psychology of Education, 18, 75-86. http://dx.doi.org/10.1007/BF03173605

Rosenberg, M. (1965). Society and the adolescent self-image. Princeton: Princeton University Press. http://dx.doi.org/10.1515/9781400876136

Şahin, E., Barut, Y., \& Ersanl, E. (2013). Parental education level positively affects self-esteem of Turkish adolescents. Journal of Education and Practice, 4(20), 87-97.

Schiraldi, G. R. (2007). 10 Simple solutions for building self-esteem. Oakland: New Harbinger Publications.

Schraw, G. (1998). Promoting general metacognitive awareness. Instructional Science, 26(1-2), 113-125. http://dx.doi.org/10.1023/A:1003044231033

Schunk, D. H. (1999). Social-self interaction and achievement behavior. Educational Psychology, 34(4), 219-227. http://dx.doi.org/10.1207/s15326985ep3404_3 
Shang, H. F. (2011). Exploring the relationship between EFL proficiency level and reading strategy use. International Journal of Humanities and Social Science, 3, 18-27.

Shaw, B. A., Liang, J., \& Krause, N. (2010). Age and race differences in the trajectories of self-esteem. Psychology and Aging, 25, 84-94. http://dx.doi.org/10.1037/a0018242

Sheldon, K. M., Elliot, A. J., Kim, Y., \& Kasser, T. (2001). What is satisfying about satisfying events? Testing 10 candidate psychological needs. Journal of Personality and Social Psychology, 80, 325-339. http://dx.doi.org/10.1037/0022-3514.80.2.325

Statman, D. (1993). Self-assessment, self-esteem and self-acceptance. Journal of Moral Education, 22, 55-62. http://dx.doi.org/10.1080/0305724930220106

Timothy, J. O., Sheldon, S., \& Norman, G. (2001). Extending self-esteem theory and research (2nd ed.). Cambridge: Cambridge University.

Topkaya, N. (2014a). Gender, Self-stigma, and Public Stigma in Predicting Attitudes toward Psychological Help-seeking. Educational Sciences: Theory \& Practice, 14(2), 480-487. https://doi.org/10.12738/estp.2014.2.1799

Topkaya, N. (2014b). Psikolojik Yardım Alma Niyetini Yordamada Demografik, Bireysel ve Çevresel Faktörler. Turk Psikoloji Dergisi, 29(74), 1-11.

Topkaya, N., \& Meydan, B. (2013). Üniversite öğrencilerinin problem yaşadıkları alanlar, yardım kaynakları ve psikolojik yardım alma niyetleri. Trakya Üniversitesi Eğitim Fakültesi Dergisi, 3(1), 25-37.

Zarei, E., Shokrpour, N., Nasiri, E., \& Kafipour, R. (2012). Self-esteem and academic success as influenced by reading strategies. English Language Teaching, 5(2), 17-26. http://dx.doi.org/10.5539/elt.v5n2p17

Zeigler-Hill, V. (2013). The importance of self-esteem. In V. Zeigler-Hill (Ed.), Self-Esteem (pp. 1-21). USA: Psychology.

Zeigler-Hill, V., \& Showers, C. J. (2007). Self-structure and self-esteem stability: The hidden vulnerability of compartmentalization. Personality and Social Psychology Bulletin, 33, 143-159. http://dx.doi.org/10.1177/0146167206294872

Zhang. (2005). Prediction of Chinese life satisfaction: Contribution of collective self-esteem. International Journal of Psychology, 40(3), 189-200. http://dx.doi.org/10.1080/00207590444000285

Zimmerman, B. (1995). Dimensions of academic self-regulation: A conceptual framework for education. In B. J. Zimmerman, \& D. H. Schunk (Eds.), Self-Regulation of Learning and Performance (pp. 3-24). Hillsdale: Lawrence Erlbaum Associates.

\section{Copyrights}

Copyright for this article is retained by the author(s), with first publication rights granted to the journal.

This is an open-access article distributed under the terms and conditions of the Creative Commons Attribution license (http://creativecommons.org/licenses/by/4.0/). 